\title{
Age-Related Macular Degeneration in Nepal
}

\author{
Thapa R, Paudyal G, Shrestha MK, Gurung R, Ruit S
}

Tilganga Institute of Ophthalmology

Gaushala, Kathmandu

Corresponding Author

Raba Thapa

Tilganga Institute of Ophthalmology

P.O. Box 561, Kathmandu, Nepal.

Email Address: rabathapa@live.com

Citation

Thapa R, Paudyal G, Shrestha MK, Gurung R, Ruit S. Age-Related Macular Degeneration in Nepal. Kathmandu Univ Med J 2011;35(3):165-9.

\section{ABSTRACT}

\section{Background}

The Age-related Macular Degeneration (AMD) is a common cause of visual impairment and blindness worldwide in elderly.

\section{Objective}

This study aimed to explore the demographic characteristics, pattern and risk factors for AMD at a tertiary referral eye centre in Nepal.

\section{Methods}

This is a hospital-based prospective study, conducted at Tilganga Institute of Ophthalmology, Nepal from September 2008 to May 2009. All the consecutive cases of AMD diagnosed at the institute were included.

\section{Results}

A total of 141 patients (266 eyes) with AMD recruited for the study. The mean age was 69.5 years (9.1SD) with three fifth males (58.9\%). Housewives and occupations like agriculture comprised of $38.3 \%$ and $42.5 \%$ respectively. Three fourth $(75.6 \%)$ of the patients were illiterate. The proportion of dry and wet AMD were found in $62.4 \%$ and $37.6 \%$ respectively. Bilateral involvement was seen in $88.7 \%$ of the subjects. Three fourth $(71.4 \%$ ) of the AMD eyes had presenting visual acuity less than $6 / 18$. History of smoking was found in $69.9 \%$ of patients. Hypertension was the predominant systemic problem (45.4\%) followed by diabetes mellitus (12.8\%).

\section{Conclusion}

AMD is correlated with ageing in our study as well. Dry AMD is more in age groups 45-64 years and wet AMD at 65 years and older. Bilateral involvement with one eye dry and fellow eye wet AMD is more predominant (44\%). Smoking and occupations like agriculture and housewife are significant risk factors for AMD. Likewise male sex, illiteracy and hypertension are other risk factors for AMD in hospital settings.

\section{KEYWORDS}

agriculture, dry macular degeneration, hypertension, illiterate, smoking, wet macular degeneration

\section{INTRODUCTION}

Age-related Macular Degeneration (AMD) is the commonest cause of irreversible blindness and visual impairment in elderly with significant public health problem in the developed and developing countries contributing $8.7 \%$ of global blindness. ${ }^{1}$ The various population based studies have shown that the prevalence of AMD was 9.1\% - 20.9\% among the whites and $3.1 \%-10.6 \%$ in Asian peoples. ${ }^{2-6}$ In a previous population based study in Nepal, AMD was found to contribute $8.7 \%$ of total blindness. ${ }^{7}$

The wet type of macular degeneration although constitutes only $10 \%$ of the AMD burden, is a main cause of irreversible vision loss. ${ }^{8}$

Although a third commonest cause of blindness in worldwide, AMD is not a priority eye disease in the poorest and most populous regions of Asia and Africa. This is compounded by the fact that the available treatment for wet macular degeneration is out of reach to the average people of the developing country.

The aim of study was to explore the demographic characteristics, pattern and risk factors for AMD at a tertiary eye care centre in Nepal. 
Table 1. Demographic information.

\begin{tabular}{|c|c|c|c|c|c|}
\hline \multicolumn{2}{|l|}{ Description } & \multicolumn{3}{|l|}{ Eyes (AMD) } & \multirow[t]{2}{*}{ Patients ( $n=141)$} \\
\hline & & $\operatorname{Dry}(\%)(n=166)$ & Wet(\%) $(n=100)$ & Total(\%)(n=266) & \\
\hline \multirow[t]{5}{*}{ Age (Years) } & $45-54$ & $8(4.8)$ & $5(5.0)$ & $13(4.9)$ & $7(5.0)$ \\
\hline & $55-64$ & $47(28.3)$ & $15(15.0)$ & $62(23.3)$ & $34(24.0)$ \\
\hline & $65-74$ & $59(35.5)$ & $41(41.0)$ & $100(37.6)$ & $52(36.9)$ \\
\hline & $75-84$ & $44(26.5)$ & $34(34.0)$ & $78(29.3)$ & $41(29.1)$ \\
\hline & $85-94$ & $8(4.8)$ & $5(5.0)$ & $13(4.9)$ & $7(5.0)$ \\
\hline \multirow[t]{2}{*}{ Sex } & Female & $81(48.8)$ & $32(32.0)$ & $113(42.5)$ & $58(41.1)$ \\
\hline & Male & $85(51.2)$ & $68(68.0)$ & $153(57.5)$ & $83(58.9)$ \\
\hline \multirow[t]{4}{*}{ Ethnicity } & Newar & $48(18.1)$ & $25(9.4)$ & $73(27.5)$ & $39(27.7)$ \\
\hline & Chhetri & $37(13.9)$ & $16(6.0)$ & $53(19.9)$ & 28(19.9) \\
\hline & Mongolian & $17(6.4)$ & $20(7.5)$ & $37(13.9)$ & $20(14.2)$ \\
\hline & Other & $12(4.5)$ & $9(3.4)$ & $21(7.9)$ & $12(8.5)$ \\
\hline \multirow[t]{5}{*}{ Occupation } & Agriculture & $61(36.7)$ & $51(510)$ & $112(42.1)$ & $60(42.6)$ \\
\hline & Housewife & $76(45.8)$ & $28(28)$ & $104(39.1)$ & $54(38.3)$ \\
\hline & Service & $10(6)$ & $9(9)$ & 19(7.1) & $10(7.1)$ \\
\hline & Business & $11(6.6)$ & $4(4)$ & $15(5.6)$ & $8(5.7)$ \\
\hline & Others & $8(4.8)$ & $8(8)$ & $16(6)$ & $9(6.3)$ \\
\hline \multirow[t]{2}{*}{ Literacy } & Literate & $37(22.3)$ & $24(24)$ & $61(22.9)$ & $33(23.4)$ \\
\hline & Illiterate & $129(77.7)$ & $76(76)$ & $205(77.1)$ & $108(76.6)$ \\
\hline
\end{tabular}

\section{METHODS}

This was a hospital-based prospective study conducted at Tilganga Institute of Ophthalmology, a tertiary eye care centre of Nepal. All the consecutive cases of AMD presented to the institute from September 2008 to May 2009 were included in the study. Patients with concurrent macular problems due to other inflammatory, retinal vascular problems and traumatic causes leading to confusions in diagnosis and grading of AMD were excluded.

History was taken in detail regarding demographic information, family history, dietary habits, details of smoking and systemic problems, focused mainly on hypertension, hyperlipidaemia and other cardiac problems. Presenting and best corrected distance visual acuity with Snellen chart was recorded. Anterior and posterior segment findings were recorded in detail under mydriasis. Findings on macula were recorded in detail like size and characters of drusens, Retinal Pigment Epithelium (RPE) pigmentary abnormalities, RPE atrophy, geographic atrophy, subretinal hemorrhage, subretinal fluids, pigment epithelial detachment and disciform fibrotic scars. Classification of AMD was done according to the international classification and grading system for age related maculopathy. ${ }^{9}$ Fundus photography, optical coherence tomography (OCT) and fundus fluorescein angiography (FFA) were done as needed. Patients were referred to physicians and cardiologist for needful treatment of the systemic problems.

Patients were recorded as hypertensive if they are taking antihypertensive medications or systolic blood pressure more than 160 and or diastolic blood pressure more than $90 \mathrm{mmHg}$ at least three times in two different recordings.
Patients were regarded diabetics if they are taking hypoglycaemic agents or fasting plasma glucose (FPG) >= $126 \mathrm{mg} / \mathrm{dl}$ ( $7.0 \mathrm{mmol}$ ) or 2 hour post prandial blood glucose >= $200 \mathrm{mg} / \mathrm{dl}(11.1 \mathrm{mmol} / \mathrm{l})$. Likewise Hyperlipidaemia was recorded if raised serum levels of one or more of the total cholesterol (TGs), low-density lipoprotein cholesterol (LDL-C), triglycerides (TGS), or both T Choland TG (combinedhyperlipidaemia) or if history of taking medication for hyperlipidaemia. The data was analyzed in SPSS 11.0 version. $P$ value of less than 0.05 was taken as significant in this study. Ethical approval was obtained from the institutional review board of the Tilganga Institute of Ophthalmology, and the study was conducted according to the principles of the Declaration of Helsinki. Informed consent was obtained from the patients before enrollment in the study.

\section{RESULTS}

A total of 141 patients (266 eyes) were included in the study. The average age of the patients was 69.5 years with a range from 46 years to 94 years of age (9.1 SD). Maximum numbers of patients were between $65-84$ years of age comprising of $66.9 \%$ of the affected eyes.

Both the dry and wet AMD cases were more with advancing age of the patient. Males were more than females comprising of $58.9 \%$ and $41.1 \%$ respectively. Brahmins (29.8\%) and Newars (27.7\%) were the predominant ethnic groups for this problem.

Patients from all the occupational groups presented with 
this problem but people who worked as farmers (42.6\%) and housewives (38.3\%) were mostly affected. $76.6 \%$ of cases were illiterate with involvement of more than three fourth $(77.1 \%)$ affected eyes (Table 1 ).

History of smoking was found in $70.2 \%$ of the cases. Among them, past smoking was found in $51.5 \%$ and smoking at the time of presentation was in $18.4 \%$. About one third of patients used to smoke more than 10 cigarettes/ day. (Table 2)

Ninety five percent of the subjects were of non-vegetarian and $94.6 \%$ of the patients were presented with the chief complaints of decrease in vision. The mean duration of decreased visionwas 12.09 months.

More than two-third affected eyes (71.4\%) had presenting visual acuity of less than 6/18. (Table 3) Astigmatism which includes both myopia and hypermetropia was the commonest refractive error among the affected eyes (54.1\%), followed by simple hypermetropia (16.5\%) and simple myopia (10.5\%). (Table 5) Cataract was the most common anterior segment finding $(70.2 \%)$ and $12.8 \%$ of the cases had already done bilateral cataract surgery.

Dry macular degeneration was more common than wet macular degeneration comprising of $62.4 \%$ and $37.6 \%$ of the eyes respectively. Bilateral involvement was found in $88.7 \%$ of the cases. Among the bilateral cases, one eye affected with dry and other eye wet macular degeneration was found in majority (44.0\%) of the cases where as bilateral dry macular degeneration was found in (40.8\%) and wet macular degeneration in (15.2\%). Among the dry AMD cases, Intermediate type was found in highest number of eyes $(50.0 \%)$. (Table 4$)$

Hypertension only was found in $45.4 \%$ of the cases. It was followed by diabetes mellitus (12.8\%), mixed diabetes and hypertension (7.8\%) and hyperlipidaemia (1.4\%).

Wet AMD was significantly higher among the occupations with agriculture, housewives $(p=0.077)$ and those with smokers $(p=0.005)$. (Table 5)

\section{DISCUSSION}

Age- related Macular degeneration is a multi factorial disease with increasing public health problem due to its irreversible vision loss in elderly not only in the developed countries but also in developing countries like Nepal.

In our study, $71 \%$ of the AMD patients were of age 65 years and older and AMD was significantly associated with increasing age $(P=0.026)$. Dry $A M D$ was found more in younger age groups (45-64 years) where as wet AMD in older age groups (65-94 years). Almost one third (33\%) of the dry AMD and one fifth (20\%) of the wet AMD were found in age groups 45-64 years where as two thirds (67\%) of dry AMD and four fifths (80\%) of wet AMD were found in age groups 65-94 years. This finding was consistent with other studies done in other countries. ${ }^{2,10,11}$ Unlike mentioned in the literatures where female sex is found as a risk factor
Table 2. Pattern of smoking.

\begin{tabular}{|c|c|c|c|c|}
\hline \multicolumn{5}{|c|}{ Eyes (AMD) } \\
\hline & & Dry $(n=166)$ & Wet $(n=100)$ & Total $(n=266)$ \\
\hline & & $\begin{array}{l}\text { Frequency } \\
\text { (\%) }\end{array}$ & $\begin{array}{l}\text { Frequency } \\
\text { (\%) }\end{array}$ & $\begin{array}{l}\text { Frequency } \\
\text { (\%) }\end{array}$ \\
\hline \multirow[t]{4}{*}{ Smoking } & Never & $60(36.1)$ & $20(20)$ & $80(30.1)$ \\
\hline & Past & $84(50.6)$ & $53(53)$ & $137(51.5)$ \\
\hline & Present & $22(13.3)$ & $27(27)$ & $49(18.4)$ \\
\hline & Total & $166(100)$ & $100(100)$ & $266(100)$ \\
\hline \multirow{3}{*}{$\begin{array}{l}\text { No of } \\
\text { cigarettes/ } \\
\text { Day }\end{array}$} & $<10$ & $115(69.3)$ & $62(62)$ & $177(66.5)$ \\
\hline & $>10$ & $51(30.7)$ & $38(38)$ & $89(33.5)$ \\
\hline & Total & $166(100)$ & $100(100)$ & $266(100)$ \\
\hline
\end{tabular}

Table 3. Presenting and best corrected visual acuity.

\begin{tabular}{lllll} 
Description & & \multicolumn{3}{c}{ Eyes (AMD) } \\
& & $\operatorname{Dry}(n=166)$ & $\operatorname{Wet}(\mathrm{n}=100)$ & Total $(\mathrm{n}=266)$ \\
\hline $\begin{array}{l}\text { Presenting } \\
\text { visual } \\
\text { acuity }\end{array}$ & $6 / 6-6 / 18$ & $72(43.4)$ & $4(4.0)$ & $76(28.6)$ \\
& $<6 / 18-6 / 60$ & $63(38.0)$ & $22(22.0)$ & $85(32)$ \\
& $<6 / 60-3 / 60$ & $14(8.4)$ & $23(23.0)$ & $37(13.9)$ \\
\hline \multirow{2}{*}{$\begin{array}{l}\text { Best } \\
\text { corrected } \\
\text { visual } \\
\text { acuity }\end{array}$} & $<3 / 60$ & $17(10.2)$ & $51(51.0)$ & $68(25.6)$ \\
& $<6 / 6-6 / 18$ & $113(68.0)$ & $9(9.0)$ & $122(45.9)$ \\
& $<6 / 60-3 / 60$ & $32(19.3)$ & $28(28.0)$ & $60(22.5)$ \\
& $<3 / 60$ & $15(9.6)$ & $16(16.0)$ & $22(8.3)$ \\
\hline & & & $47(47.0)$ & $62(23.3)$ \\
\hline
\end{tabular}

Table 4. Laterality and severity of AMD.

\begin{tabular}{|c|c|c|c|c|c|}
\hline \multicolumn{2}{|c|}{ Description } & \multicolumn{4}{|c|}{ Eyes (AMD) } \\
\hline & & \multirow{2}{*}{$\begin{array}{l}\text { Dry } \\
\text { Freq (\%) }\end{array}$} & \multirow{2}{*}{$\begin{array}{l}\text { Wet } \\
\text { Freq (\%) }\end{array}$} & \multirow{2}{*}{$\begin{array}{l}\text { Mixed } \\
\text { (dry + } \\
\text { wet) } \\
\text { Freq (\%) }\end{array}$} & \multirow{2}{*}{$\begin{array}{l}\text { Total } \\
\text { Freq (\%) }\end{array}$} \\
\hline & & & & & \\
\hline \multirow{3}{*}{$\begin{array}{l}\text { Laterality } \\
(n=141)\end{array}$} & Bilateral & $51(40.8)$ & 19(15.2) & $55(44.0)$ & 125 (88.7) \\
\hline & Unilateral & $9(56.3)$ & $7(43.7)$ & $0(0)$ & $16(11.3)$ \\
\hline & Total & $61(43.3)$ & 25 (17.7) & 55 (39.0) & $\begin{array}{l}141 \\
(100.0)\end{array}$ \\
\hline \multirow{2}{*}{\multicolumn{2}{|c|}{$\begin{array}{l}\text { Severity of Dry AMD } \\
(n=100)\end{array}$}} & Mild & $\begin{array}{l}\text { Interme- } \\
\text { diate }\end{array}$ & Severe & Total \\
\hline & & $79(47.6)$ & $83(50.0)$ & $4(2.4)$ & \\
\hline
\end{tabular}

for AMD we found males more with the problems although women were more likely to develop dry than wet AMD $(P=0.042 \text {, odds ratio }=1.983, \mathrm{Cl} 1.019-3.876)^{2,10,12}$ This may be due to privilege of males for health facilities. We found the AMD higher among peoples with occupations of agriculture and housewives who used to spend their time longer in the fields. This may be due to higher sunlight exposure as compared to other occupational groups. ${ }^{11-14}$ More than three fourth of our study cases were illiterate who don't have knowledge about the disease, relative lack of good nutrition and also ork more in the field with 
Table 5. Risk factors analysis for AMD.

\begin{tabular}{|c|c|c|c|c|c|}
\hline Description & & Dry & Wet & Total & P-value \\
\hline \multirow[t]{5}{*}{ Age } & $45-54$ & 3 & 4 & 7 & \multirow[t]{5}{*}{0.169} \\
\hline & $55-64$ & 27 & 7 & 34 & \\
\hline & $65-74$ & 29 & 23 & 52 & \\
\hline & $75-84$ & 26 & 15 & 41 & \\
\hline & $85-94$ & 4 & 3 & 7 & \\
\hline \multirow[t]{2}{*}{ Sex } & Female & 42 & 16 & 58 & \multirow[t]{2}{*}{0.056} \\
\hline & Male & 47 & 36 & 83 & \\
\hline \multirow[t]{5}{*}{ Ethnicity } & Brahmin & 27 & 15 & 42 & \multirow[t]{5}{*}{0.47} \\
\hline & Newar & 27 & 12 & 39 & \\
\hline & Chhetri & 18 & 10 & 28 & \\
\hline & Mongolian & 9 & 11 & 20 & \\
\hline & Others & 8 & 4 & 12 & \\
\hline \multirow[t]{2}{*}{ Literacy } & Literate & 19 & 14 & 33 & \multirow[t]{2}{*}{0.514} \\
\hline & Illiterate & 69 & 39 & 108 & \\
\hline \multirow[t]{5}{*}{ Occupation } & Agriculture & 33 & 27 & 60 & \multirow[t]{5}{*}{0.077} \\
\hline & Housewife & 40 & 14 & 54 & \\
\hline & Service & 5 & 5 & 10 & \\
\hline & Business & 7 & 1 & 8 & \\
\hline & Others & 4 & 5 & 9 & \\
\hline \multirow[t]{2}{*}{ Smoking } & Never & 31 & 11 & 42 & \multirow[t]{2}{*}{0.005} \\
\hline & Present/Past & 58 & 41 & 99 & \\
\hline \multirow[t]{2}{*}{ HTN } & No & 52 & 25 & 77 & \multirow[t]{2}{*}{0.234} \\
\hline & Yes & 37 & 27 & 64 & \\
\hline \multirow[t]{2}{*}{ DM } & No & 76 & 47 & 123 & \multirow[t]{2}{*}{0.391} \\
\hline & Yes & 13 & 5 & 18 & \\
\hline \multirow{2}{*}{$\begin{array}{l}\text { HTN/ DM } \\
\text { Mixed }\end{array}$} & No & 82 & 48 & 130 & \multirow[t]{2}{*}{0.971} \\
\hline & Yes & 7 & 4 & 11 & \\
\hline \multirow{4}{*}{$\begin{array}{l}\text { Pattern of } \\
\text { refractive } \\
\text { error }\end{array}$} & Astigmatism & 103 & 41 & 144 & \multirow{4}{*}{0.860} \\
\hline & Hypermetropia & 27 & 17 & 44 & \\
\hline & Myopia & 17 & 11 & 28 & \\
\hline & No error & 19 & 31 & 50 & \\
\hline
\end{tabular}

longer UV exposure without protection. But there was no significant difference with the types of AMD $(P=0.077)$ among different occupational groups.

Newar and Brahmin were the predominant ethnic groups for the problem although it was not statistically significant with the type of AMD ( $p=0.470)$. This might be due to the catchment areas of the eye institute where more people are from Newar and Brahmin ethnic groups. Population based study will be needed for further analysis.

Smoking history was found in more than two-third of our cases out of which one third were present smokers. We found the significant association between past and current smoking with wet AMD $(P=0.005$, Odds Ratio $=0.442$, $95 \% \mathrm{Cl}$ 0.246-0.792) as in other studies. ${ }^{15-20}$ There was no significant association between the number of sticks smoked and wet or dry AMD ( $P=0.097)$.
The poor visual acuity at the time of presentation may be due to late presentation and co-existing cataract. The delayed presentation may be due to the lack of awareness of the seriousness of the problem and poor transportation facilities from the remote areas as almost half of the cases were from out of the Kathmandu valley and painless nature of the problem.

We found no significant association of myopia or hypermetropia with either types of AMD $(P=0.860)$ unlike in other literatures where hypermetropia was a risk factor. 10,12

Unlike described in the literatures the higher number of wet AMD cases in this study may be due to the lack of knowledge on regular eye check-up among patients where most of the people presented late once they had marked diminution of vision, the main feature of wet AMD. ${ }^{8,12}$

Hypertension was found in nearly half of our study subjects. Although not statistically significant $(P=0.234)$ with either types of AMD it could be one of the risk factors for the causation of AMD in our patients as in other studies. ${ }^{10,21-23}$ The other systemic conditions in our patients were diabetes mellitus, mixed diabetes and hypertension, hyperlipidaemia and other cardiovascular problems, although the association was not statistically significant with the types of AMD (DM P=0.391, HTN+ DM P=0.971).

For the analysis of risk factors of all types of AMD, we need the control group who do not have any changes of AMD. This was not done in our study and is the limitation of this study.

\section{CONCLUSION}

AMD is a common retinal problem with emerging public health challenge in elderly of the developing countries like Nepal. Dry AMD is more common in age groups $45-64$ years and wet $A M D$ at 65 years and older. Bilateral involvement with one eye dry and fellow eye wet AMD is more predominant than bilateral involvement with single type. Smoking and occupations like agriculture and housewife were risk factors for AMD. Likewise, male sex, illiteracy and hypertension were other risk factors for dry and wet AMD in hospital patients. Public awareness on these modifiable risk factors and regular eye check up after 50 years of age could help to limit the disease and its burden of blindness. We recommend further community based studies for the additional risk factors.

\section{ACKNOWLEDGEMENT}

We would like to thank Robert Dashwood (Australia), Nhukesh Maharjan, and Bikram Dahal from the Research Department of this Institute for their contribution and hard work during the data and statistical analyses of this study. The authors also would like to thank Mr. Radha Krishna Suwal, Bhaisharan Thapa and Rajak Khah from the 
vitreo-retina unit for their contribution on investigation procedures of AMD. Likewise, we are very grateful to all the ophthalmologists of the Tilganga Institute of
Ophthalmology and other eye hospitals for referring the patients with AMD making this study possible.

\section{REFERENCES}

1. Resnikoff S, Pascolini D, Etya'ale D, Kochur I, Pararajasegaram R, Pokhrel GP, et al. Global data on visual impairment in the year 2002. Bulletin of World Health Organization 2004; 82: 844-51.

2. Klein R, Klein BEK, Linton KLP. Prevalence of Age-related Maculopathy. The Beaver Dam Eye Study. Ophthalmology 1992; 99: 933-43.

3. Mitchell P, Smith W, Attebo K, Wang JJ. Prevalence of agerelated maculopathy in Australia. The Blue Mountains Eye Study. Ophthalmology 1995; 102:1450-60.

4. Nirmalan PK, Robin AL, Katz J, Tielsch JM, Thulasiraj RD, Krishnadas $\mathrm{R}$, et al. Prevalence of vitreoretinal disorders in a rural population of southern India: the Aravind Comprehensive Eye Study. Arch Ophthalmol 2004; 122:581-6.

5. Gupta SK, Murthy GV, Morrison N, Price GM, Dherani M, John N, et al. Prevalence of early and late age-related macular degeneration in a rural population in northern India: the INDEYE feasibility study. Invest Ophthalmol Vis Sci 2007; 48:1007-11.

6. Wu LH. Study of aging macular degeneration in China. Jpn J Ophthalmol;31: 349-67.

7. Sapkota YD, Pokharel GP, Nirmalan PK, Dulal S, Maharjan IM \& Prakash K. Prevalence of Blindness and cataract surgery in Gandaki Zone, Nepal. Br J Ophthalmol 2006; 90:411-16.

8. Ryan SJ. Retina. IN: Bressler NM, Bressler SB, Fine SL,eds. Neovascular(Exudative) Age -related macular degeneration. 4th ed. Philadelphia, USA: Elsevier Mosby; 2006. P. 1075-13.

9. Bird AC, Bressler NM, Bressler SB, Chisholm IH, Coscas G, Davis MD, et al. An international classification and grading system for age- related maculopathy age-related macular degeneration. The international ARM Epidemiological Study group. Surv Ophthalmol 1995; 39(5):36774.

10. Chaine G, Hullo A, Sahel J Soubrane G, Espinasse-Berrod M, Schutz D, et al . Case- control study for the risk factors for age related macular degeneration. Br J Ophthalmology 1998; 82: 996- 1002.

11. Wierzbowska J, Figurska M, Stankiewicz A, Sierdzinski J. Risk factors in age-related macular degeneration and glaucoma--own observations. Klin Oczna 2008; 110(10-12):370-4.

12. American Academy of Ophthalmology. Retina and vitreous; Basic and clinical science course, section 12. San Francisco, CA, USA: 2008-2009. P. 60-90.
13. Tomany SC, Cruickshanks KJ, Klein R, Klein BE, Kundtson MD. Sunlight and the 10 -year incidence of age -related maculopathy: the Beaver Dam Eye Study. Arch Ophthalmol 2004; 122(5): 750-7.

14. Cruickshanks KJ, Klein R, Klein BE, Nondahl DM. Sunlight and the 5 -year incidence of early age- related maculopathy: the beaver dam eye study. Arch Ophthalmol 2001; 119(2):246-50.

15. Hawkins BS, Bird A, Klein R, West SK. Epidemiology of Age-related macular degeneration. Molecular vision 1999; 5:26.

16. Chakravarthy U, Augood C, Bentham GC, de Jong PT, Rahu M, Seland J, et al. Cigarette smoking and age-related macular degeneration in the EUREYE Study. Ophthalmology 2007; 114 (6):1157-63.

17. Seddon JM, George S, Rosner B. Cigarette smoking, fish consumption, omega-3 fatty acid intake, and associations with Age-Related Macular Degeneration. Arch Ophthalmol 2006; 124(7): 995-1001.

18. Khan JC, Thurlby DA, Shahid H, Clayton DG, Yates JRW, Bradley M et al. Smoking and age related macular degeneration: the number of pack years of cigarette smoking is a major determinant of risk for both geographic atrophy and choroidal neovascularization. $\mathrm{Br} J$ Ophthalmol 2006; 90:75-80.

19. Age-Related Eye Disease Study Research Group. Risk Factors for the Incidence of Advanced Age-related macular Degeneration in the Age-Related Eye disease Study (AREDS) AREDS Report No. 19. Ophthalmology 2005; 112(4): 533-539.

20. Klein R, Knudtson MD, Cruickshanks KJ, Klein BE. Further observations on the association between smoking and the long-term incidence and progression of age-related macular degeneration: the Beaver Dam Eye study. Arch Ophthalmol 2008; 126(1): 115-21.

21. Klein R, Klein B, Tomany SC, Cruickshanks KJ.The association of cardiovascular disease with the long -term incidence of age- related maculopathy. Ophthalmology 2003; 110:1273-1280.

22. Van LR, Ikram MK, Vingerling JR, Witteman JCM, Hofman A, de Jong PTVM. Blood pressure, atherosclerosis, and the incidence of agerelated maculopathy. The Rotterdam Eye Study. Invest Ophthalmol Vis Sci 2003; 44:3771-77.

23. Hyman L, Schachat AP, He Q, Leske MC. Hypertension, cardiovascular disease, and age- related macular degeneration. Age- Related Macular Degeneration Risk Factors Study Group. Arch Ophthalmol 2000; 118(3):351-8. 